\title{
Ruptured Dermoid Cyst during Pregnancy: A Rare Case Report
}

\author{
Himanshu Chaudhary, Aditi Jindal* and Priyanka Sharma \\ Department of Obstetric and gynaecology, Indira Gandhi Medical College, India \\ Submission: May 05, 2018 ; Published: June 15, 2018
}

"Corresponding author: Aditi Jindal, Department of Obstetric and gynaecology, Indira Gandhi Medical College, Shimla, India, Tel: +919816496649; Email: aditijindal_18@yahoo.com

\begin{abstract}
Aim: We are presenting a rare case report of ruptured mature cystic teratoma during pregnancy.

Background: Mature cystic tutors arise from all the germ cell layers. They have a low malignant potential. They are the most common ovarian tumors presenting in the antenatal period, usually present in the second trimester of pregnancy.

Case description: We hereby present a rare case report of ruptured mature cystic teratoma during pregnancy. She was an unbooked patient who presented to us for the first time at 24 weeks with pain abdomen with previous one lower segment caesarean section. She was posted for emergency laparotomy with the suspicion of ovarian cyst torsion. Intraoperatively there was ruptured dermoid cyst in the left ovary. Oopherectomy was performed. She had an uneventful postoperative period.
\end{abstract}

Conclusion: The most common complication of mature cystic teratoma during pregnancy is torsion. Rupture of a mature cystic teratoma is a rare complication with the reported incidence of $0.2-0.5 \%$.

Clinical Significance: Rupture of dermoid cyst is a rare complication but usually requires surgical intervention.

Keywords: Ruptured dermoid cyst; Pregnancy; Chemical peritonitis

\section{Background}

Mature cystic teratoma are cystic tumors derived from the germ cell layers [1]. It typically contains mature tissues of ectodermal (skin, brain), mesodermal (muscle, fat), and endodermal (mucinous or ciliated epithelium) origin. Mature cystic teratoma is the most common benign ovarian tumor in the reproductive age group. It accounts for 20 percent of adult ovarian tumor [2]. The incidence of rupture of mature cystic teratoma varies between 0.2 to $2.5 \%$ and the typical presentation is insidious with granulomatous peritonitis. There have been only a few descriptions about rupture of ovarian dermoid tumor during pregnancy in literature.

\section{Case Description}

An unbooked 28 year old second gravida, at 24 weeks pregnancy, with previous lower segment caesarean section, presented to us with complaints of pain abdomen since last two days. She had no antenatal visits during pregnancy till now. On general physical examination patient had tachycardia. On abdominal examination there was tenderness on deep palpation however no guarding or rigidity was appreciated. Height of uterus was corresponding to the period of gestation with no suprapubic tenderness. On per vaginal examination os was closed and there was tenderness in the left fornix. An emergency ultrasound was done which revealed a single live intrauterine fetus with a $5 \times 6 \mathrm{~cm}$ left adenexal mass which showed no vascularity on doppler. With the suspicion of ovarian cyst torsion, patient was posted for emergency laprotomy.

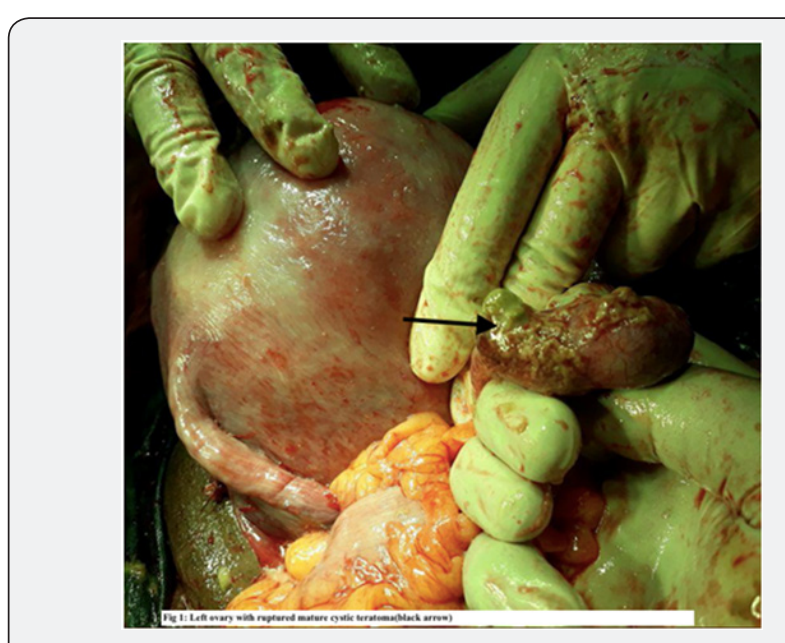

Figure 1: Left ovary with ruptured mature cystic teratoma (black arrow). 
Under spinal anaesthesia, abdomen was opened by a midline vertical scar. Intraoperatively there was cheesy material all over the abdomen densely adherent to the uterus and the gut. Gut was explored for any enteric pathology. Bilateral ovaries were visualised. There was a $4 \times 5 \mathrm{~cm}$ ruptured ovarian cyst in the left ovary (Figure 1). Decision of oophorectomy was taken and peritoneal lavage done. On gross examination, the cyst contained pultaceous material with hair (Figure 2) Specimen was sent for histopathological examination (HPE). Her postoperative period was uneventful and patient was discharged in satisfactory condition on the $7^{\text {th }}$ post operative day. The HPE report confirmed the diagnosis of dermoid cyst.

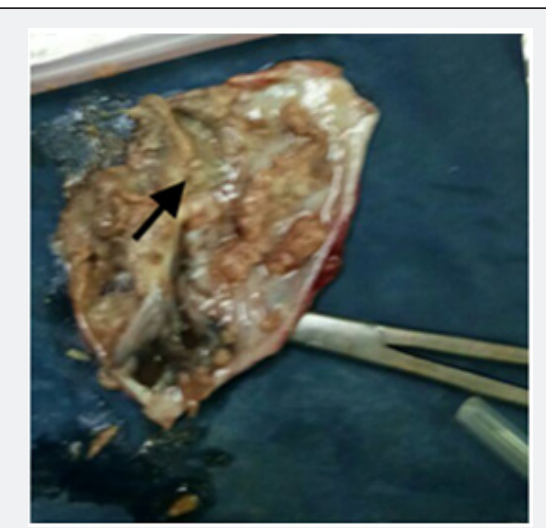

Figure 2: Cut section showing pultaceous material (black arrow).

\section{Discussion}

Mature cystic teratoma usually presents in the reproductive age group. It is usually asymptomatic and diagnosed on routine ultrasonographic examination. The most common complication of mature cystic teratoma is torsion. There have been rare instances of rupture, malignant transformations.

The incidence of rupture is 0.2 to $2.5 \%$. The rare incidence of rupture is attributed to the thick capsule. Dermoid cyst rupture can be primary or secondary. Primary rupture usually occur after torsion, infarction, infection, malignancy or following prolonged pressure due to pregnancy or delivery. Secondary rupture of dermoid cyst may be iatrogenic or following vigorous exercise. Rupture of the teratoma results in leakage of sebaceous material causing an aseptic inflammatory peritoneal reaction leading to chemical peritonitis. The presentation of ruptured dermoid cyst may be acute or chronic. In acute presentation the patient may present as acute abdomen. A similar case has been reported by Chang Y et al. [1] where patient presented after vigorous physical activity. In chronic presentation the patient may present as chronic granulomatous peritonitis, there may be omental deposits mimicking ovarian carcinoma $[3,4]$. There have been case reports of dermoid cyst with gliomatosis peritonei [5].

Dermoid cyst may remain asymptomatic during pregnancy, and if symptomatic usually has symptoms in the second trimester. The most common pregnancy related complication of dermoid cyst is torsion. There have been few cases of dermoid cyst rupture during pregnancy and at the time of delivery. Maiti S et al. [4] described a similar case of dermoid cyst rupture during pregnancy in early third trimester at 31 weeks where as Nader R et al described rupture of dermoid cyst after delivery [6].

A mature cystic teratoma can be diagnosed at ultrasonography by diffusely or partially echogenic mass with the echogenic area owing to sebaceous material and hair within the cavity. There may be free fluid levels resulting from sebum floating above aqueous fluid, which appears more echogenic than the sebum layer. The diagnosis of mature cystic teratoma at computed tomography (CT) or magnetic resonance imaging (MRI) is fairly straight forward [7]. Usually an asymptomatic dermoid cyst may not require any intervention in less than $6 \mathrm{~cm}$ tumors [8]. Ruptured dermoid cyst usually require surgical intervention.

Here we have described a rare case of ruptured dermoid cyst during pregnancy.

\section{Clinical Significance}

a) Rupture of dermoid cyst is a rare complication but usually requires surgical intervention.

b) Dermoid cyst is the most common ovarian germ cell tumor during pregnancy.

c) Ruptured dermoid cyst may mimic ovarian malignancy.

d) Usually can be diagnosed by USG, MR or CT.

\section{Declaration}

Contributors: HC, AJ and PS were involved in the patient management. HC wrote the manuscript. PS contributed in the literature search and corrections in the manuscript. All authors have read and approved the final version of the manuscript.

Consent: Patient consent was obtained.

\section{References}

1. Arab H (1993) Gestational Diabetes: Regional Experience. Postgraduate Doctor 16(12): 196-202. 70825239 cas ref

2. Langer 0 (1998) Maternal Glycemic Criteria for Insulin Therapy in Gestational Diabetes Mellitus. Diabetes Care 21(suppl 2): B91-B98.

3. Heller S, Peter D, Mersebach H, Vang T, Kaaja R, et al (2010) Hypoglycemia in Type 1 Diabetic Pregnancy. Diabetes Care 33(3): 473477.

4. Rizza RA (1985) Production of insulin resistance by hyperinsulinemia in man. Diabetologia 28(2): 70-75.

5. Prato DS, Leonetti F, Simonson DC, Sheehan P, Matsuda M, et al. (1994) Effect of sustained physiologic hyperinsulinemia and hyperglycemia on insulin secretion and insulin sensitivity in man. Diabetologia 37(10): 1025-1035.

6. Henry R, Gumbiner B, Ditzler T, Wallace P, Lyon R, et al. (1993) Intensive conventional insulin therapy for type II diabetes. Metabolic effects during a 6-mo outpatient trial. Diabetes Care 16(1): 21-31.

7. Dimitriadis G, Mitrou P, Lambadiari V, Maratou E, Raptis SA, et al. (2011) Insulin effects in muscle and adipose tissue. Diabetes Res Clin Pract 93(Suppl 1): S52-S59. 
8. Jolly MC, Sebire NJ, Harris JP, Regan L, Robinson S, et al (2003) Risk factors for macrosomia and its clinical consequences: a study of 350,311 pregnancies. Eur J Obstet Gynecol Reprod Biol 111(1): 9-14.

9. Holman RR, Kerensa IT, Farmer AJ, Davies MJ, Keenan JF, et al. (2007) Addition of biphasic, prandial or basal insulin to oral therapy in type 2 diabetes. N Engl J Med 357: 1716-1730.

10. Rasmussen SA, Chu SY, Kim SY, Schmid CH, Lau J, et al. (2008) Maternal obesity and risk of neural tube defects: a meta-analysis. Am J Obstet Gynecol 198(6): 611-619.

11. Ricart W, López J, Mozas J, Pericot A, Sancho MA, et al. (2005) Body mass index has a greater impact on pregnancy outcomes than gestational hyperglycaemia. Diabetologia 48(9): 1736-1742.

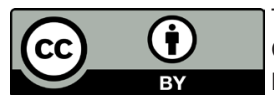

This work is licensed under Creative Commons Attribution 4.0 License

DOI: $10.19080 / J G W H .2018 .10 .555781$
12. Cundy T, Greg G, Leonie N, Rose E, Paul MP, et al. (2007) Differing Causes of Pregnancy Loss in Type 1 and Type 2 Diabetes. Diabetes Care 30(10): 2603-2607.

13. Jovanovic (1999) Effect of Diet and Exercise in managing uncontrolled gestational diabetes. Diabetes 40(Suppl 2): 179-181.

14. NICE Guideline (NG3) (2015) Diabetes in Pregnancy: management from preconception to the postnatal period.

\section{Your next submission with Juniper Publishers will reach you the below assets}

- Quality Editorial service

- Swift Peer Review

- Reprints availability

- E-prints Service

- Manuscript Podcast for convenient understanding

- Global attainment for your research

- Manuscript accessibility in different formats

( Pdf, E-pub, Full Text, Audio)

- Unceasing customer service

Track the below URL for one-step submission https://juniperpublishers.com/online-submission.php 